J O U R N A O F French and Francophone Philosophy
RE V UE DE LA

philosophie française et de langue française

\title{
The Impossible Logic of Assimilation
}

\section{Robert Bernasconi}

Journal of French and Francophone Philosophy - Revue de la philosophie française et de langue française, Vol XIX, No 2 (2011) pp 37-49

\author{
Vol XIX, No 2 (2011) \\ ISSN 1936-6280 (print) \\ ISSN 2155-1162 (online) \\ DOI $10.5195 /$ jffp. 2011.490 \\ www.jffp.org
}

\section{(c)) BY-NC-ND}

This work is licensed under a Creative Commons Attribution-Noncommercial-No Derivative Works 3.0 United States License.

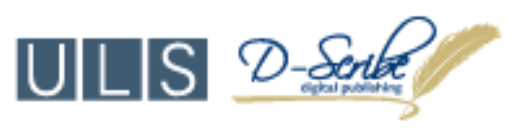

This journal is operated by the University Library System of the University of Pittsburgh as part of its D-Scribe Digital Publishing Program, and is co-sponsored by the University of Pittsburgh Press 


\title{
The Impossible Logic of Assimilation
}

\author{
Robert Bernasconi \\ Pennsylvania State University
}

What makes Albert Memmi's descriptions of both the colonizer and the colonized so compelling is that they are drawn from personal experience. To this extent at least they are even more instructive than, for example, JeanPaul Sartre's legendary account of anti-Semitism, to which they are nevertheless clearly indebted. ${ }^{1}$ Memmi is particularly well-placed to write an account of the experiences of both the colonizer and the colonized because he played more than one role in the drama. This is what he was alluding to when he emphasized his identity as "an Arab Jew." As an Arab in Tunisia he knew what it was to be colonized. The Jews in Tunisia also ranked among the colonized, but they did not experience oppression in the same way as the Moslems did. ${ }^{2}$ For example, the Jews experienced the arrival of the Europeans as a sort of liberation. Similarly, the Jews experienced the process of decolonization differently from the Arabs. As an Arab Jew, Memmi had an unusual level of insight into the pressures governing the forces described in The Colonizer and the Colonized: "I was a sort of half-breed of colonization, understanding everyone because I belonged to no one." 3 It is this "ambiguity" that enables him to see so clearly what I shall call "the paradox of assimilation." The Jewish population is made up of "eternally hesitant candidates refusing assimilation" but in an understandable effort to escape the colonized condition, "they endeavor to resemble the colonizer in the frank hope that he may cease to consider them different from him." 4 That is to say, the Jews "endeavored to identify themselves with the French," an option not given to Moslems, but as a Tunisian national the ambition was never going to be fulfilled. 5

In this essay I argue that Memmi's analysis in The Colonizer and the Colonized transcends the colonial situation of the 1950s. The remorseless logic exposed by Memmi, whereby the colonizer and the colonized are locked together in mutual dependence within a polarized society, applies whenever a dominant group insists that various minorities conform to the role 
assigned to them. Memmi's philosophical and literary works, read with reference to the logic of assimilation, retain a wider application beyond the immediate context for which they were written. To make that point I will sometimes refer to "the oppressor" and "the oppressed" rather than "the colonizer" and "the colonized," and in partial justification for doing so, I draw attention to Memmi's own use of the terms "les dominants" and "les dominés" in other works. ${ }^{6}$

The first part of The Colonizer and the Colonized presents Memmi's "Portrait of the Colonizer." It begins by recording the process by which Europeans newly arrived in the colonies become not only educated in colonial practices, but also caught up in a process which they could not avoid and over which they have no control. Memmi points to the advantages that colonials receive simply by virtue of being European in a country where the low wages paid to the local inhabitants allows them to enjoy a higher standard of living than would be available to them in their home country. Of course, it is also true that those low wages benefit the people in the so-called "mother country," but Memmi's concern is with the process by which a European cannot stay for long in a colony without becoming a colonizer. It comes about by virtue of the privileges the colonizer automatically enjoys whether he or she wants to or not, so that there is ultimately no such thing as a European living in a colony that does not have the colonizer's attitude toward the colonized. ${ }^{7}$ It is ultimately not up to the newcomer whether or not he or she is received as a privileged person. Privilege is already guaranteed by the institutions, the customs, and the people there. Furthermore, there are severe pressures on such a person to pass to the next stage, that of the colonizer who accepts his or her role and adjusts his or her life to fit the ideology already in place. Memmi calls such a person "a colonialist": "to be a colonialist is the natural vocation of a colonizer."8 Memmi explains how racism comes to symbolize "the fundamental relation which unites colonialist and colonized." 9 It arises from a refusal on the part of the colonialists to allow for the equality between the colonialist and the colonized which would require the colonialist to give up their privileges. This "colonial racism" is lived. To that extent, it is unlike the doctrinal racism of the Europeans, who develop racial theories from a distance.

Although the colonialists find themselves inevitably incorporated among the elite, there are other groups that have an ambiguous status, and so are neither colonizers nor colonized. Here Memmi's analysis focuses for a moment specifically on Tunisia. There are the Maltese who maintain a different, closer, relation to the colonized than do the French; there are those among the colonized who serve as representatives of the authorities and who adopt the colonizer's ideology "even with regard to their own values and their own lives"; there are the Corsicans who, recently assimilated, "push a colonial mentality to excess"; and finally there are the Jews, who 
live in what Memmi describes as painful and constant ambiguity because while refusing assimilation, they try to be like the colonizers in the hope that their differences from them will be overlooked. ${ }^{10}$ In trying to resemble the colonizers, the colonized only magnify the differences. But, in spite of everything that separates these groups, they share an opposition to the colonizer. This is because, as Memmi puts it, "The crushing of the colonized is included among the colonizer's values." 11 To be like the colonizer the colonized must hate the colonized. That is to say, the colonized must reject him- or her-self. This, one is told, happens not infrequently. ${ }^{12}$ But, one might add, if the colonized hates him- or herself, it is not in the way that the colonizers hate themselves, if and when they come to think of themselves as guilty.

Sartre claims that Memmi sees a situation, where he himself, alluding to a contemporary essay entitled "Colonialism is a System," sees a system. ${ }^{13}$ The difference can easily be exaggerated. What difference would it make if the word "system" was substituted for "situation" in the following sentence from The Colonizer and the Colonized: "The colonial situation manufactures colonialists, just as it manufactures the colonized."14 It is no doubt true but at the same time insufficient simply to say that what marks the difference is the lack of the dialectical method. In the course of explaining how Sartre's account of the system is dialectical, one would come up against the notion of reciprocity. ${ }^{15}$ This notion of reciprocity is at the heart of Sartre's Critique of Dialectical Reason, as it is at the heart of Frantz Fanon's The Wretched of the Earth, but it is already developed by Memmi, and Sartre himself noticed it there already in his review of the first edition of the book for Les Temps Modernes which was included in subsequent editions as a Preface. ${ }^{16}$ The reciprocity is most apparent in the desire on the part of the colonizer to exterminate the colonized. The colonizer is led to such a desire out of a Nero Complex, in an effort to be free of guilt. But the process is self-defeating. ${ }^{17}$ To remove the colonized would be the end of colonialism not its fulfillment: "Along with the colonized, colonization would disappear, and so would the colonizer." 18

In The Liberation of the Jew Memmi recalls the pressures of assimilation as he experienced them in Tunisia, including the way that scorn for the assimilated was complicated by class issues. Memmi notes how, over and beyond strictly religious rites and values, there is inevitably uncertainty as to which of the so-called Jewish customs are borrowed and which are not. ${ }^{19}$ He also dwells on the difficulty any one individual might face in attempting to assimilate without taking one's group and one's memories with one: "In effect, how could I pass unnoticed if my parents, my friends, my relatives, continued to reveal my identity?" 20 Memmi is also an accomplished novelist, and he discusses the same problems in a fictional setting in his novel, The Pillar of Salt. A Jew and an Arab, the protagonist is torn "between the East and the West, between African superstitions and philosophy, between our 
dialect and the French language." 21 The two parts of his being speak two different languages and do not communicate to each other. "I was both myself and a stranger." 22 At a certain point the protagonist gives up his ambition to be a doctor and chooses philosophy. However, in the face of anti-semitism he becomes disillusioned with philosophy.

How vain and futile are all theoretical and philosophical constructions of the world when compared to the brutal realities of the world! The European philosophers build the most rigorous and virtuous moral codes, and their politicians, brought up by these teachers, foment murders as a means of government. ${ }^{23}$

He becomes involved in radical politics, but he persuades himself that this is not by choice but forced on him by the situation. ${ }^{24}$ A further change comes over him during the Second World War when he realizes that, as an intellectual, he has been spared internment in one of the camps. He asks to be allowed to join the camp workers. "Painfully but definitely, I was discovering that others really existed, and moreover that I would never be content merely with my own happiness." 25 It is an observation about experience that ultimately has more to say about ethics than some moral philosophers manage in a lifetime.

In The Colonizer and the Colonized Memmi already recognizes the problem of assimilation, but he seems to present it as a problem limited to the colonial situation: "within the colonial framework, assimilation has turned out to be impossible." 26 With reference to the attempt on the part of the Jews of Tunisia to resemble the colonizer in the hope that they would no longer be considered different, Memmi observes that, without always openly discouraging such efforts, the colonizer nevertheless never permits them to be successful. ${ }^{27}$ Nevertheless, Memmi does not think that the failure of assimilation is logically necessary: "I will not even say that it is impossible by definition." 28 The emphasis begins to change in The Liberation of the Jew, where Memmi formulates the following law, which he insists is as true for all other oppressed groups, women and Blacks, as well as for Jews: "Assimilation was necessary and, as long as the oppression lasted, assimilation had to fail." 29 Furthermore, Memmi's argument is now not only that history has so far not presented the entire Jewish group with the possibility to assimilate; logic forbids it also.

To propose assimilation globally to a group is, in the final analysis, absurd. As the philosophers would say, it contradicts its own essence. In order to assimilate, a group must consent, if only confusedly. Now it is clear that a group, inasmuch as it is a group, cannot assimilate. It cannot want to go against its own existence, for then it would be rejecting itself. ${ }^{30}$

Memmi introduces a caveat. There have been examples of mass assimilation, but only when the alternative to metamorphosis was 
extermination. However, this only serves to highlight the paradox: "One cannot ask a group to renounce its own existence in order to save itself since this formal existence coincides with its very life as a group. Outside of itself, it is literally nothing since it becomes something else." 31 This is a logic imposed on the Jews from outside. My concern here is with this impossible logic of assimilation that is imposed by the oppressors on the oppressed. It is encapsulated in the demand "Become like us," a demand that is nevertheless issued in the knowledge that the one to whom it is addressed can never be like "us" because he or she is not "one of us." To the extent that the oppressed are fooled by this invitation, not least because the circumstances may provide a powerful motive leading them to want to believe, they are destined to be cheated again. Memmi expresses it with characteristic simplicity: "In order to be assimilated, it is not enough to leave one's group, but one must enter another; now he meets with the colonizer's rejection." 32

Memmi refers to a kind of vertigo that accompanies the process of assimilation leading the Jew to refuse being submerged in the dominant culture with the result that he clings to what he was before. But the real obstacle to assimilation lies not in this vertigo, but rather in the fact that true assimilation could only be conversion, and thus a form of extermination. ${ }^{33}$ Perhaps assimilation could take place over time, but it could never be a project freely chosen by the group. It is not like what happens when the members of a club specifically founded to perform some task or bring about some end agree to disband their organization when their goal is accomplished. In this case, they have to assert their distinctiveness in order to deny it.

More specifically, racism will sometimes lead the dominant group to insist that a minority assimilates, but at the same time this racism serves as an obstacle. The circumstances that put pressure on a group to assimilate, also contributes to making assimilation impossible. Under conditions of racism, a people does not of its own free-will pursue assimilation, any more than they would, in the final analysis, be allowed to assimilate. ${ }^{34}$ The demand that a specific group assimilates affirms the group in its existence at the same time as calling on it to disband itself. Irrespective of whether the dominant group would ever allow this process of assimilation to be accomplished, it is enough that the demand to assimilate be issued for its failure to be guaranteed. Memmi observes that the reason why "an oppressor can almost never swallow up another people by violence" is because violence awakens the oppressed. ${ }^{35}$ If one recognizes the demand to assimilate as itself an act of violence in this sense, it can be understood why it invariably fails. The very dominance that makes it possible for one group to issue such a demand to another separates the group from those to whom the demand is directed. The first step on the way to breaking down the polarization of the two groups would be for the one group to renounce its dominance over the other, but this would also remove the demand. In 
addition to being so unlikely as to be unheard of, it does not resolve the paradox.

There are therefore two kinds of assimilation: assimilation to the dominant group, to which the oppressed are called but from which they are forever excluded, and assimilation into racism, which is the inevitable fate of the newly arrived colonizer. It is true that Memmi does not express himself in quite that way, but it is suggested by his analysis of the Corsicans in Tunisia and Spaniards in Algeria, whom he calls "recently assimilated." $36 \mathrm{He}$ could as easily have referenced the racism learned and adopted by certain immigrant groups in the United States as a condition of being counted as White. Memmi describes a process by which the colonial mentality, including disdain for the colonized, is exaggerated. Foreigners, whose vulnerability make them ready targets of racism, can be used to bolster the ranks of the dominant class if they exhibit sufficient disdain, in this racism, against those lower in the pyramid to establish their loyalty to the system of privilege already in place.

Nevertheless, in 2004 Memmi published Decolonization and the Decolonized, to the dismay of some of those who had previously read him with such enthusiasm. This is not the occasion for me to respond to the book as a whole, but as the question might arise as to whether Memmi has backed away from precisely those aspects of his analysis that I have been praising, I must say something about it. Memmi is clear: "Black Americans are not a decolonized people, although they have certain traits in common with them, just as they have certain traits in common with the colonized." 37 However, my argument is not that Black Americans are not decolonized, but that the impossible logic of assimilation that Memmi portrayed as governing the situation of the colonized can equally apply to Black Americans. But Memmi's provocative style leads him to accuse African Americans of dolorism, that is to say, of the "natural tendency to exaggerate one's pains and attribute them to another." 38 No doubt this is true of some African Americans, but Memmi seems oblivious to the White Americans who blame everything on Black people.

Victimization is one of the recurrent themes of the book.39 So in Decolonization and the Decolonized the impossible logic of assimilation sinks into the background in the description of Black Americans, but it reappears in his discussion of the immigrant. Having seemingly castigated the immigrant for failing to integrate, ${ }^{40}$ Memmi finally acknowledges that this is at very least a two-sided affair. He writes of Europe's relation to the former colonized who were now immigrants: "to assimilate them, it must not only welcome them but have the capacity to absorb them. This time it is doubtful that it can, or even that it wants to." 41 And he recognizes that poor Blacks in France experience additional problems because of their color. 42 So the impossible logic of assimilation is still intact in Memmi and the only puzzle is why he refuses to apply it in his discussion of African Americans who are 
blamed for not acting as Asians or Italians in the United States did. ${ }^{43}$ The generous reader will do so on Memmi's behalf, but it is to be regretted that the author of Racism does not more clearly correct the calumnies he attributes to his friends that African Americans do not prosper because they have, as a result of slavery, a mentality that discourages them from forming associations to help each other. Memmi's writing is strongest when he writes from experience and in this case he is writing from a distance.

There is little comfort for anybody in Memmi's account. The startingpoint of his 1965 essay on "Racism and Oppression" is the claim that "Everyone, or nearly everyone, is an unconscious racist, or a semi-conscious one, or even a conscious one." 44 Racial prejudice is, Memmi argues, "a social fact." $45 \mathrm{He}$ understands this to mean that racism exists in institutions, ideologies, education and culture, before being in the individual. This leads to the question of what Memmi calls "the surprising racism of the oppressed." Memmi explains the racism between oppressed groups as arising from the fact that no group wants to find itself at the bottom of the ladder. "So it is," says Memmi, "that the American Jew may be tempted to scorn the American Black, who reciprocates heartily." 46 The diagnosis of that particular example is no doubt too quick, but in general it is true that one oppressed group can try to direct attention away from itself by offering another group as a scapegoat. ${ }^{47}$ Memmi does not accept the argument that the oppressed cannot by definition be racist. The claim that racism is only possible among those who are already in some way empowered is, so far as he is concerned, refuted by simple observation. ${ }^{48}$ Nor does Memmi try to calculate who is most oppressed and so least likely to be racist. Nevertheless, as he explains in The Colonizer and the Colonized, there is, aside from the aggressive racism of the colonizers, a defensive racism of the colonized, which is social and historical as distinct from being biological and metaphysical. ${ }^{49}$ In assessing the racism of the oppressed, one must always look beyond the language in which it is couched to the structure from which it emerges. ${ }^{50}$

The privileged need to be constantly reminded of the conditions that sustain their position. Racism, like anti-Semitism, is not simply a question of personal attitudes, but is more pervasive and more deeply rooted in the very structures of society than the privileged individual wants to believe. But the privileged in one context may lose those privileges in another context, and vice versa. Memmi teaches an invaluable lesson when he highlights how the structure of repression is complex and the identity of oppressor and oppressed can shift across different contexts.51 Someone who may be oppressed in the work place may well be an oppressor in relation to his or her neighbors or in the home. Memmi recognizes this when he turns his attention specifically to oppressed women:

I hope that all I am about to say will be treated as highly suspect: for the first time in my life I am on the wrong side 
of the fence; in talking about women, I observe, with embarrassment and a touch of malice, that this time I am to be counted among the oppressors. ${ }^{52}$

Possibly that was the first time he felt himself to be unambiguously among the oppressors. ${ }^{53}$ To be sure, women constitute a large part of humanity! Perhaps the degree to which he had failed to highlight before that time the condition of women shows the degree to which he had taken the standpoint of an oppressor in this regard. Even so, acting as an oppressor in one context did not make him any more acceptable to those who refused to recognize him as like them. That is once again the paradox of assimilation.

1 Jean-Paul Sartre, Réflexions sur la question juive (Paris: Paul Morihen, 1946); trans. George J. Becker, Anti-Semite and Jew (New York: Schocken, 1948). For a comparison of Sartre's book with that of Memmi, see Jonathan Judaken, Jean-Paul Sartre and the Jewish Question (Lincoln: University of Nebraska Press, 2006), 165166.

2 Albert Memmi, Juifs et Arabes (Paris: Gallimard, 1974), 70; trans. Eleanor Levieux, Jews and Arabs (Chicago: J. Philip O'Hara, 1975), 40.

3 Albert Memmi, Portrait du colonisé précédé du Portrait du colonisateur (Paris: Gallimard, 1985), 20; trans. The Colonizer and the Colonized (New York: Orion Press, 1965), xvi.

${ }^{4}$ Memmi, Portrait du colonisé, 44; trans. The Colonizer, 15.

${ }^{5}$ Memmi, Portrait du colonisé, 18; trans. The Colonizer, xiii-xiv.

${ }^{6}$ For example, Albert Memmi, Portrait du décolonisé (Paris: Gallimard, 2004), 114 and 128; trans. Robert Bononno, Decolonization and the Decolonized (Minneapolis: University of Minnesota Press, 2006), 94 and 128.

${ }^{7}$ Memmi, Portrait du colonisé, 45 and 39; trans. The Colonizer, 17 and 10.

${ }^{8}$ Memmi, Portrait du colonisé, 70; trans. The Colonizer, 45.

${ }^{9}$ Memmi, Portrait du colonisé, 92; trans. The Colonizer, 70. 
${ }^{10}$ Memmi, Portrait du colonisé, 43-44; trans. The Colonizer, 15-16.

${ }^{11}$ Memmi, Portrait du colonisé, 138; trans. The Colonizer, 121.

${ }^{12}$ Memmi, Juifs et Arabes, 37; trans. Jews and Arabs, 87.

13 Jean-Paul Sartre, "Le colonialisme est un système," Situations $V$ (Paris: Gallimard, 1964), 25-48; trans. Azzedine Haddour, et al., "Colonialism is a System," Colonialism and Neocolonialism (London: Routledge, 2001), 30-47. The essay was originally published in Les Temps Modernes 123 (1956): 1371-1386.

${ }^{14}$ Memmi, Portrait du colonisé, 79-80; trans. The Colonizer, 56.

15 Jean-Paul Sartre, Critique de la raison dialectique (Paris: Gallimard, 1960), 200224; trans. Alan Sheridan-Smith, Critique of Dialectical Reason (London: NLB, 1976), 122-152.

${ }^{16}$ Frantz Fanon, Les damnés de la terre (Paris: Gallimard, 1991), 122; trans. Richard Philcox, The Wretched of the Earth (New York, Grove Press, 2004), 46. Memmi, Portrait du colonisé, 157; trans. The Colonizer, 145. Sartre, "Preface," in Portrait $d u$ colonisé, 26; trans. The Colonizer, xxviii. Sartre's so-called "Preface" first appeared as a review in Les Temps Modernes 137-138 (July-August 1957): 289-293. It was not in the first edition published by Buchet/Chastel in 1957 and seems to have been introduced first into the English translation published by Orion Press in 1965. Its first appearance in a French language edition was in the following year by JeanJacques Pauvert of Utrecht. This edition was dedicated to French Canadians as the American edition was dedicated to "the American Negro, also colonized."

${ }^{17}$ Memmi, Portrait du colonisé, 77-78; trans. The Colonizer, 53-54.

${ }^{18}$ Memmi, Portrait du colonisé, 161; trans. The Colonizer, 149.

${ }^{19}$ Memmi, La libération du juif (Paris: Gallimard, 1966), 46-51; trans. Judy Hyun, The Liberation of the Jew (New York: Orion, 1966), 55-59.

${ }^{20}$ Memmi, La libération, 52; trans. The Liberation, 60. Memmi suggests that the urge to assimilate is present in all oppressed groups. Whether they are Black, Jewish 
or colonized, they strive to resemble the White, the non-Jew, the colonizer: "the colonized in the throes of assimilation hides his part, his traditions, in fall all his origins which have become ignominious" (Portrait du colonisé, 139; trans. The Colonizer, 122). Memmi fails to explore the differences between the groups or even the familiar question of the fact that it is easier for some groups, or more precisely, some individuals within those groups to pass unnoticed among the oppressors than it is for others. Memmi's interest is not in the details, but in establishing a more general framework.

21 Albert Memmi, La statue du sel (Paris, Gallimard, 1966), 247; trans. Edouard Roditi, The Pillar of Salt (Boston, Beacon Press, 1992), 229.

${ }^{22}$ Memmi, La statue du sel, 248; trans. The Pillar of Salt, 230.

${ }^{23}$ Memmi, La statue du sel, 290; trans. The Pillar of Salt, 269.

${ }^{24}$ Memmi, La statue du sel, 279; trans. The Pillar of Salt, 259.

${ }^{25}$ Memmi, La statue du sel, 305; trans. The Pillar of Salt, 282.

${ }^{26}$ Memmi, Portrait du colonisé, 140; trans. The Colonizer, 123.

${ }^{27}$ Memmi, Portrait du colonisé, 44; trans. The Colonizer, 15.

${ }^{28}$ Memmi, Portrait du colonisé, 161; trans. The Colonizer, 149.

${ }^{29}$ Albert Memmi, La libération, 51; trans. The Liberation, 59.

${ }^{30}$ Memmi, La libération, 52-53; trans. The Liberation, 60-61.

${ }^{31}$ Memmi, La libération, 53; trans. The Liberation, 61.

${ }^{32}$ Memmi, Portrait du colonisé, 140; trans. The Colonizer, 124.

${ }^{33}$ Memmi, Portrait du colonisé, 37; trans. The Colonizer, 86-87. However, even conversion has not guaranteed assimilation. Indeed, it is sometimes said the first instance of racism arose in connection with the provisions in sixteenth century Spain directed specifically to Christians of Jewish descent, the conversos. See Richard 
Popkin, "The Philosophical Basis of Modern Racism" in The High Road to Pyrrhonism (San Diego: Austin Hill, 1980), 72-102. Although Memmi does not give the same unique importance to the purity of blood statutes as Popkin does, he acknowledges their historical significance in Le racisme, 91-92; trans. Racism, 75-76.

${ }^{34}$ Memmi, Portrait du colonisé, 140; trans. The Colonizer, 124.

${ }^{35}$ Memmi, La libération, 54; trans. The Liberation, 62.

${ }^{36}$ Memmi, Portrait du colonisé, 42; trans. The Colonizer, 13.

${ }^{37}$ Memmi, Portrait du décolonisé, 34; trans. Decolonization and the Decolonized, 19.

${ }^{38}$ Memmi, Portrait du décolonisé, 35; trans. Decolonization and the Decolonized, 18.

39 See Memmi, Portrait du décolonisé, 83 and 116; trans. Decolonization and the Decolonized, 65 and 96.

40 Memmi, Portrait du décolonisé, 134 and 146; trans. Decolonization and the Decolonized, 113 and 124.

${ }^{41}$ Memmi, Portrait du décolonisé, 148; trans. Decolonization and the Decolonized, 126.

42 Memmi, Portrait du décolonisé, 137; trans. Decolonization and the Decolonized, 116.

43 Memmi, Portrait du décolonisé, 34; trans. Decolonization and the Decolonized, 19.

${ }^{44}$ Albert Memmi, L'homme dominé (Paris: Gallimard, 1968) 307; trans. Dominated Man (New York: Orion Press, 1968) 186.

${ }^{45}$ Memmi, L'homme dominé, 208; trans. Dominated Man, 197.

${ }^{46}$ Memmi, L'homme dominé, 211; trans. Dominated Man, 200. 
${ }^{47}$ Memmi, La libération, 58; trans. The Liberation, 67.

${ }^{48}$ Albert Memmi, Le racisme (Paris: Gallimard, 1994), 45-46, 50, 119, 122, 147-148, and 222-228; trans. Steve Martinot, Racism (Minneapolis: University of Minnesota Press, 2000), 30, 34, 107-110, 136, and 197-203. I should add that to my mind these more general books suffer from what seems like a surprising lack of knowledge about the history of the science of race (as evidenced in his attempt to make the concept of a pure race "the essential foundation of racism") and a level of confusion over whether or not racism has an institutional reality before becoming an ideology (as his discourse on "legitimation" and "justification" suggests). Nevertheless, the book is full of wisdom as is especially clear when he moves from the philosophy of racism to some practical lessons (see Le racisme, 158-177; trans. Racism, 146-165).

${ }^{49}$ Memmi, Portrait du colonisé, 147; trans. The Colonizer, 131.

50 Most readers of Memmi encountered this point already in Sartre's preface to Memmi's The Colonizer and the Colonized in the form of an objection that Memmi's focus on the individuals involved in the colonial drama was at the price of an examination of the colonial system in which they are embedded (see Portrait $d u$ colonisé, 24-25; trans. The Colonizer, xxiii). Memmi was presumably not hostile to this observation as it must have been with his permission that the so-called preface was republished. It was in fact Sartre's review of the first edition for Les Temps Modernes which appeared in July-August 1957, nos. 137-138: 289-293. So far as I can tell, Sartre's review was first added as a Preface to the edition published by JeanJacques Pauvert of Utrecht that appeared in 1966, pp. 31-36. The edition was dedicated by Memmi to French Canadians "because they wanted to be Canadians and French" (14).

${ }^{51}$ Consider in this regard one of the chapter titles to Gabrielle Simon Edgcomb's From Swastika to Jim Crow: Refugee Scholars at Black Colleges (Melbourne, FL: Krieger, 1993): ““. . . Now Suddenly I Was on the Other Side, I Belonged Not to the Oppressed but to the Oppressor."”

${ }^{52}$ Memmi, L'homme dominé, 155; trans. Dominated Man, 141.

53 For Memmi's own nuanced view of his assimilation to the oppressing group, see his "Itinéraire de l'expérience vécue à la théorie de la domination" in Albert 
Memmi, Un Entretien avec Robert Davies (Quebec: Editions l'Étincelle, 1975), 4146. 